https://doi.org/10.18485/iipe_60nam.2021.ch10

\title{
THE NON-ALIGNED MOVEMENT FIGHT FOR THE NEW INTERNATIONAL ECONOMIC ORDER
}

\author{
Sanja JELISAVAC TROŠÍć ${ }^{1}$
}

\begin{abstract}
The New International Economic Order (NIEO), conceived as an idea and need among Non-Aligned countries, formalized through the United Nations Declaration on the Establishment of a New International Economic Order and the Programme of Action on the Establishment of a New International Economic Order, proposed a revolutionary reform of the world economic order established after the Second World War. The crisis of the functioning and development of the world economy during the 1970s led to negative consequences, especially for underdeveloped countries and countries that have just freed themselves from colonialism, and in a world full of divisions, there were thoughts and plans to resolve the general crisis in the world economy and international relations in general. The NIEO called for reformist interventions in international institutions, economic structures and mechanisms to stop treating developing countries as passive subjects of the international economic order, as well as measures to reduce the growing economic gap between developed and developing countries. After the initial success and enthusiasm that reigned among the Non-Aligned Movement, the whole initiative began to fade and give way to new current world crises. Part of the many demands for change that constituted the essence of the NIEO continued their individual lives and with more or less success, with more or less modifications, they found their place in the regulation of economic
\end{abstract}

\footnotetext{
${ }^{1}$ Senior Research Fellow, Institute of International Politics and Economics, Belgrade. E-mail: sanja@diplomacy.bg.ac.rs.

The paper presents findings of a study developed as a part of the research project "Serbia and challenges in international relations in 2021", financed by the Ministry of Education, Science, and Technological Development of the Republic of Serbia, and conducted by the Institute of International Politics and Economics, Belgrade.
} 
relations among states. However, each new crisis, which is spreading more and more rapidly among the countries of the whole world, already makes this forgotten initiative modern again.

Key words: Non-Aligned Movement, New International Economic Order (NIEO), developing countries, world economy.

\section{Introduction}

The Non-Aligned Movement was formed during the Cold War as an organisation of states that did not seek to formally align themselves with either the United States or the Soviet Union. This movement developed gradually in the post-war years until the first complete platform was drawn up at the Conference in Belgrade in 1961 on the basis of which the NonAligned Movement acted from then on (Mates, 1985, p. 73). At the beginning of the 1970s, when the world economy already suffered from a series of grave crises, member states of the Non-Aligned attention focused on the need to change the existing and establish a new economic order in the world. The Non-Aligned Movement leaders met for the Fourth Summit Conference in Algeria in September 1973, and among other issues, measures have been formulated to build the New International Economic Order (NIEO). The conference adopted the Political Declaration, the Economic Declaration, the Action Program for Economic Cooperation, the Declaration on the Struggle for National Liberation and several other resolutions on current world issues. Because of the globalisation of the world economy and a significant intensity of economic relations between countries in the world, the effects of the crisis quickly spread to other countries (Bjelić, Jelisavac Trošić, Popović Petrović, 2010. p. 347). The clash of the economic crises with the existing global economic system, which had devastating consequences, especially on the developing countries, developed an interstate activity in order to reach a global agreement. The New International Economic Order, as defined at the Fourth Summit Conference of the Non-Aligned Movement, was finally formulated at the Sixth Special Session of the General Assembly of the United Nations (UN). The Declaration on the Establishment of a New International Economic Order, together with the Programme of Action on the Establishment of a New International Economic Order in practice, was adopted by the United Nations General Assembly in May 1974 (United Nations, 1974a, 1974b). The New International Economic Order required major and substantial changes, but Non-Aligned countries have shown great maturity in formulating this initiative because the obligations of the developed countries to the NIEO did not imply that only industrialised 
western countries should carry the burden of obligation. Even though the major responsibility rests upon them, all developing countries, from East to West, have the obligation for ending inequality and poverty internationally. The quality of life of people on this Earth is not only an economic or social concern but a moral issue that concerns us all. A large section of humanity has poor living conditions, and this should be an issue of global survival (Ramphal, 1975, p. 12).

\section{Literature review}

Most of the research papers dealing with the topic of the new international economic order were written during the 1970s and 1980s when this topic was very relevant. During that period, there were several projects, proceedings, conferences, round tables and other types of research on the NIEO. Special attention should be paid to the final study New International Economic Order Pathways of Realisation and Perspectives (Popović and Štajner, 1981), and to the collections of papers from the scientific gathering on the economic aspects of the policy of Non-alignment (Adamović,1985.). There are also opinions that the NIEO is a result of a view on the economic order from the socialist corner (Zurawicki, 1982). International trade, industrialisation, political institutions and institutions of the New International Economic Order were explored in the policy studies, like Lozoya and Green (1981) and Laszlo and Kurtzman (1981). Different opinions from the scientific gathering dedicated to the NIEO can be found in Raičević and Popović (1977). In the book, Singh Shankar traces the evolution of the NIEO (1977), step by step and the events that have begun to transform the idea into reality. It is worth mentioning another study by Jagdish Bhagwan (1977) that studied the NIEO from the specific point of view of its impact on resource transfers, international trade, world food problems, technology transfer and diffusion. We must not forget the official Non-Aligned Movement and UN documents, primarily the United Nations General Assembly Resolution 3201 (S-VI): Declaration on the Establishment of a New International Economic Order and the United Nations General Assembly Resolution 3202 (S-VI): Programme of Action on the Establishment of a New International Economic Order. With the decline in interest in the new international economic order and the questions it raises, the number of papers and conferences dealing with these issues has fallen sharply. We are now witnessing the reshaping of the global economic and political order once again, and it would be good to recall the once-great ideas and initiatives, among which we can certainly consider the NIEO. 
This paper will focus on the New International Economic Order, its beginnings within the Non-Aligned Movement, postulates and institutionalisation through the UN. It will assess the content of this initiative as well as the fate it has experienced.

\section{The role of the Non-Aligned Movement in conceiving the New International Economic Order}

The global economic system, represented by the International Monetary Fund, the International Bank for Reconstruction and Development - IBRD (which today is part of the World Bank Group), and the General Agreement on Tariffs and Trade - GATT, was established after the Second World War through the negotiations of the Western developed countries. The United States were the leader in this newly established Bretton Woods system while developing countries remained outside the negotiations and the creation of the international economic system. The post-war period was difficult for all countries, but especially for those who only freed themselves from colonial rule in the years following the end of the Great War. It was a time when many countries were liberated from colonialism, but the benefits of economic development and technological progress were not shared equitably in the world. In the divided world, from North to South, from developed to underdeveloped, divided by military or political blocks, the Non-Aligned Movement pointed to a set of universal objectives reflecting aspirations to an overall change of international political and economic relations, pushing the boundaries of the world order to be acceptable for all countries, without the matter of their individual political, economic, cultural or social systems. As a new factor in international relations, the Non-Aligned Movement was pointing not only to the major problems of the post-war world, political, economic, and social and others, but also was offering ways of solving them. The Non-Aligned Movement from the very beginning emphasised the growing need to solve key economic problems (Frangeš, 1985, p. 259). The issue of the establishment of the NIEO was formally first expressed in a political declaration adopted at the Fourth Conference of the Non-Aligned Movement, held in Algiers, the capital city of Algeria, from 5 to 9 September 1973. This Declaration invited the Secretary-General of the United Nations to convene a sixth special session of the General Assembly which would be devoted to the development and international economic cooperation. The principles of the NIEO were gradually developed within the Non-Aligned Movement and were laid down as original principles by 
these member countries. There are many principles on which the NIEO is based, but here we will point out four:

1. The principle of non-reciprocity of benefits in trade and development between the underdeveloped and developed;

2. The principle of non-discrimination among countries;

3. The principle of one-sided preferential treatment of developing countries by the developed and,

4. The expansion of the general scheme of preferential treatment (Mrkušić, 1985, p. 248).

It is important to point out that the economic policy of the Non-Aligned Movement existed before the concept of the NIEO appeared, and that the economic policy of the Non-Aligned Movement will be necessary also in the future, irrespective of the NIEO's fate. (Kovač, 1985, p. 265).

\section{The UN Declaration on the establishment of the New International Economic Order}

The many problems that face individual and groups of countries cannot be successfully solved separately from the major world problems. The United Nations as a universal organisation is the right place for dealing with international economic and social problems in order to ensure equality for all. The UN, among others, is devoted to the consideration of the most important economic problems facing the world community. Algeria, on behalf of the Non-Aligned Movement, by communications of 9 October 1973 and 22 November 1973, transmitted the documents of the Conference to the Secretary-General, requesting him to issue them as an official document of the General Assembly under several items on its agenda. At the 229th plenary meeting in May 1974, the United Nations General Assembly has adopted the Declaration on the Establishment of a New International Economic Order and the Programme of Action on the Establishment of a New International Economic Order. These documents were adopted bearing in mind the spirit, purposes and principles of the Charter of the United Nations to promote the economic advancement and social progress of all people in the world. According to the United Nations, the NIEO should be "based on equity, sovereign equality, interdependence, common interest and cooperation among all States, irrespective of their economic and social systems which shall correct inequalities and redress existing injustices, make it possible to eliminate the widening gap between the developed and 
the developing countries and ensure steadily accelerating economic and social development and peace and justice for present and future generations" (UN, 1974a). The formation of the NIEO stemmed from the understanding that the prosperity of the international community as a whole depends upon the prosperity of its constituent parts - the developing countries and the developed countries, both. The NIEO rests on respect of many principles in order to secure the prosperity of developing countries and better cooperation between developed and developing ones. The principles call upon the adoption of special measures in favour of the least developed, landlocked and island developing countries. The principles of the NIEO acknowledge the right of every country to self-determination, sovereignty, non-interference, choosing an economic and social system, real participation in solving the world economic problems, right of liberalisation from apartheid, right to restitution, and many others. This initiative is trying to secure favourable conditions in the economic and social areas for developing countries. The United Nations Programme of Action on the Establishment of a New International Economic Order confirms that action needs to be taken regarding the severe economic imbalance between the developed countries and developing countries. This Programme was adopted with the aim to ensure the application of the Declaration on the Establishment of the NIEO. All efforts should be made to:

- solve fundamental problems of raw materials and primary commodities as related to trade and development;

- reform the international monetary system;

- encourage the industrialisation of the developing countries;

- encourage the transfer of technology;

- formulate, adopt and implement an international code of conduct for transnational corporations;

- expand co-operation among developing countries at the regional, subregional and interregional levels (United Nations, 1974b).

This Programme includes measures to encourage the above-mentioned for the developing countries, especially for the least developed and landlocked countries. The UN, also under this Programme, launched a Special Programme to provide emergency relief and development assistance to the developing countries most seriously affected by the economic crisis to help them overcome their present difficulties and achieve self-sustaining economic development. The UN Programme also refers to the Charter of Economic Rights and Duties of States which shall constitute an effective 
instrument towards the establishment of a new system of international economic relations based on equity, sovereign equality, and interdependence of the interests of developed and developing countries. The Charter of Economic Rights and Duties of States arose out of necessity to establish generally accepted norms to govern international economic relations systematically. The Charter acknowledges the urgent need to evolve a substantially improved system of international economic relations, and establishes the fundamentals of international economic relations. The Charter covered the economic rights and duties of states and common responsibilities towards the international community. (United Nations, 1974c). "All States have the duty to contribute to the balanced expansion of the world economy, taking duly into account the close interrelationship between the well-being of the developed countries and the growth and development of the developing countries, and the fact that the prosperity of the international community as a whole depends upon the prosperity of its constituent parts" (United Nations, 1974c, Article 31). As we see, establishing the NIEO has as a general goal to bring about maximum economic co-operation and understanding among all countries based on the principles of dignity and sovereign equality between them regardless of the chosen model of internal state organisation. All UN Member States have pledged to make full use of the UN system in the implementation of the Programme of Action on the Establishment of the NIEO, and in working for the establishment of the New International Economic Order and thereby strengthening the role of this organisation in the field of world-wide cooperation for economic and social development.

\section{The Importance of the New International Economic Order}

The proposal of the New International Economic Order was a very brave and radical move. The transnational governance reform initiative of this sort was the number one initiative from that period and accordingly was the most widely discussed topic among politicians, scientists and the general public. The fundamental objective of the NIEO - to transform the governance of the global economy - and the number of countries that supported that idea was the power that could not be ignored. It was a proposal for a radically different future than the one we actually live in. On the eve of completing the geopolitical process of decolonisation, the NIEO initiative brought ideas that would benefit more to the international integration, and it should be redirected towards the developing countries. From a moral point of view, it was an attempt to equalise the starting positions of the 
countries as much as possible before entering the market competition. Although it was a new, fresh and inspiring idea of the 1970s, it started to fade from global discussions during the second part of the 1980s and was replaced by other topics that were considered urgent and more important. By the late 1990s, the North has dismissed this idea as irrelevant, and today in most parts of the world the initiative of the NIEO is almost completely forgotten (Figure 1).

Figure 1: Mentioning the term "New International Economic Order" in Google Ngram, 1970-2019

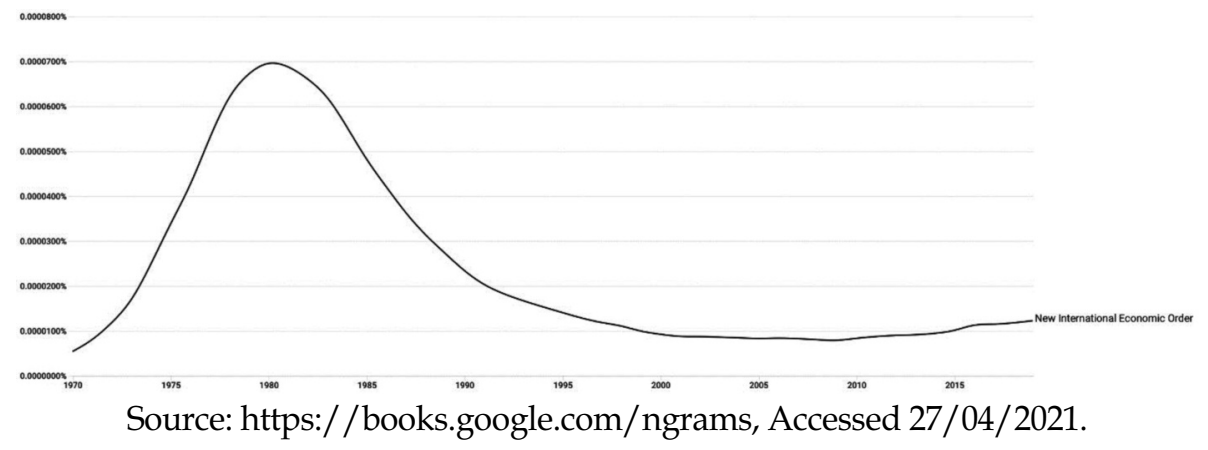

The initiative for the NIEO tackled many questions and economic problems and was not a coherent entity. Inside of the NIEO, we can find several agendas which were loosely compatible. The most important goal of the NIEO was to improve the economic position of developing countries in the international economy. The basis of the NIEO is an agenda on how to reform the international economic order in order to enable balanced progress of developing countries as well. "In particular, the NIEO Declaration called for:

- an absolute right of states to control the extraction and marketing of their domestic natural resources;

- the establishment and recognition of state-managed resource cartels to stabilise (and raise) commodity prices;

- the regulation of transnational corporations;

- no-strings-attached technology transfers from North to South;

- the granting of preferential (nonreciprocal) trade preferences to countries in the south; and 
- the forgiveness of certain debts that states in the south owed to the North" (Gilman, 2015, p. 3).

But it was not just the economic objectives of the NIEO that were important. What is also important to note with the NIEO is that there were new tools that sought to implement their economic goals through new mechanisms of international law. Advocates of the NIEO felt that existing international law is unsuited to promote structural reform, which was necessary for the development of this initiative. Therefore, in order to establish the NIEO, it was necessary to change the existing international legal order in a way that takes into account the unfavourable position of developing countries in relation to developed countries. Therefore, the correction of economic inequalities would be achieved, not only directly, but also indirectly through the correction of legal inequalities. Apart from the fact that the NEIO was primarily an economic initiative in terms of its content and goals, it was also a political initiative. The NIEO was more than just a set of technical economic-legal proposals, it was also an attempt to extend the realignment of international power that the process of decolonisation had begun. At the level of political identity, the G-77 and the NIEO claimed to embody the idea that the developing countries formed a coherent political group, one whose common political identity rested on a shared history of resistance to colonialism and imperialism (Ferguson Jr, 1977, p. 147). It was a very strong political message to the countries of the former colonisers.

\section{Success or a failure for the New International Economic Order?}

The Non-Aligned Movement has identified economic underdevelopment, poverty, and social injustices as growing threats to peace and security. There are opinions that to get rid of neocolonialist aspirations and to utilise the natural wealth of one's own country in order to promote national socioeconomic development is considered to be the first economic principle of nonalignment (Bekić, 1985, p. 87). At the time when the idea was born and when the principles were formed, the New International Economic Order caused a big international interest. Countries that wanted the NIEO initiative to be implemented have made efforts to activate and implement as many proposals as possible in various UN bodies, other international institutions or forums, such as the WB, IMF, GATT, through regulations or practices of these institutions. On the other hand, although they declaratively supported the NIEO, as well as global sovereign equality of states and the need to help the 
poorest, developed countries have taken a few steps to make this initiative really begin to live and grow in reality. The energy and hope that brought together countries around the NIEO started to disappear as rapidly as it was clear that developed countries were unwilling to respond with any major and tangible concessions. Western Europe was expected to take measures in the spirit of the new economic order, and they did that. There is, of course, a dilemma as to whether the measures taken are far-reaching enough or remain in the dimension of a gesture. The willingness or unwillingness of adequate actions will enable the developing countries to appraise the sincerity and cooperativeness of their partners, their wisdom and the ability to put their wisdom into practice (Mandi, 1975, p. 10-11). It was immediately clear that the materialisation of the NIEO, due to the very large volume of changes required, is a long process since the problems are many and accumulated. The gradual realisation of the NIEO required dialogue and negotiations between developed and developing countries. The world economic system is weighted against the weak and in favour of the strong. Developed countries with their measures, which may not even be directed against developing countries, often harm the interests of the same. Many of today's developed industrial countries used various mechanisms to spur the growth of markets in their early stages of development. Many developing countries pursued ill-considered trade, credit, and industrial policies with poor results (Jelisavac Trošić, 2018, p. 278). The fight against poverty, against the uneven distribution of the bounty of our planet among its entire people, is important. How to fight against poverty - to equalise mechanisms for disadvantaged and depressed regions of the world, persisting on the economic and social rights, by helping the poor and disadvantaged, to fight inequality in all places and all areas of life and human activities. Ensuring that every person on this planet is guaranteed the minimum tolerable conditions of human existence, of food, of health, of the habitat. To achieve this, we must move towards the NIEO. The Declaration on the Establishment of a New International Economic Order inspired a certain degree of confidence in the developing countries, but the confidence lasts only from the formulation of the principles to the switch over to action. After a while, if the statements and promises are not followed by actual agreements and effective measures, optimism turns into pessimism and frustration (Mandi, 1975, p. 11). The progress towards the creation of the NIEO has generally been slow, mostly as a result of the reticence of the developed countries. Developed industrialised countries refrained from any disturbance in the long-established world economic mechanism which has thus far given them considerable benefits and enhanced their advantageous position. The post-war period has been a period of rapid expansion of economic activity 
and interaction among an unprecedented number of subjects, and the volume of international trade raised to an unpredicted level. (Mates, 1985, p. 73). The Bretton Woods system was developed on the basis of agreement among the developed industrialised countries, and the less developed countries were left behind. So, the Non-Aligned Movement geared towards a revision of already established rules, regulations and relations in the political and economic order. The UN considers that the 2030 Agenda for Sustainable Development (Resolution 70/1), the Addis Ababa Action Agenda of the Third International Conference on Financing for Development (Resolution 69/313, annexe), and the Paris Agreement adopted under the United Nations Framework Convention on Climate Change (FCCC/CP/2015/10/Add.1, decision 1/CP.21, annexe) carry forward many of the ideas and recommendations of the Declaration on the Establishment of a New International Economic Order and the Programme of Action on the Establishment of a New International Economic Order (United Nations, 2018). Also, the realisation of the NIEO was a condition for a developing country support for the Tokyo Round of trade negotiations, and after that for the Uruguay Round. The Doha Round of negotiations, the first round in the WTO, would not even start before developed countries were obligated to do much more of a substance for developing countries, hence the informal name the Doha Development Round (Jelisavac Trošić, 2015, p. 175).

The North-South relationship is a relationship between the developed industrialised countries and the less developed countries, referred to as the developing countries. The differences in the level of development and the problems of North-South relations cannot be resolved solely by removing the barriers resulting from administrative and other state actions. The problems are much more complex (Mates, 1985, p. 75). The developed countries cannot be forced to change their attitude and lift barriers or introduce any kinds of preferential treatment for the less developed countries. The abolition of administrative barriers, facilitation of trade, encouraging exports, preferential treatment and the like, increase chances for the improvement of the balance of payments of the less developed countries, and foreign exchange earnings and to some extent employment increased. But it would be naive to believe that such limited and marginal effects can produce such changes which would lead to a narrowing of the gap between the North and the South (Mates, 1985, p. 76-8). The developing countries, which constitute $70 \%$ of the world's population, account for only $30 \%$ of the world's income in the 1970s. Today, economic advances around the world have led to the situation that while fewer people live in extreme poverty, almost half the world's population -3.4 billion people - still struggles to 
meet basic needs. While rates of extreme poverty have declined substantially, falling from 36 per cent in 1990, 26.2 per cent of the world's population (over 1.9 billion people), were living on less than $\$ 3.20$ per day, and close to 46 per cent of the world's population was living on less than \$5.50 a day, in 2015 (World Bank, 2018). It is painfully obvious that the challenge in eradicating poverty still exists today despite the all-encompassing progress of the human race, and that world hunger does not exist because we cannot feed the poor but because we cannot feed the rich. Today we hear that we should focus our efforts on building equal, inclusive and sustainable economies and societies. The UN Sustainable Development Goals are a call for action by all countries to promote prosperity while protecting the planet. They start from the notion that ending poverty must go hand-in-hand with strategies that build economic growth and address a range of social needs, including education, health, social protection, job opportunities, and others while tackling climate change and environmental protection. The most important sustainable developmental goal is to end poverty. Globally, the number of people living in extreme poverty declined from 36 per cent in 1990 to 10 per cent in 2015. But new research warns that the economic fallout from the global COVID-19 pandemic could increase global poverty by as much as half a billion people or $8 \%$ of the total human population. This would be the first time that poverty has increased globally in thirty years since 1990 (United Nations, 2021). The newest crisis, caused by the COVID-19 pandemic, has brought to the fore the need to build states, economies and societies to be more resilient in the face of pandemics, climate change or many other global challenges we face today and will face in the future. The world also needs to further the reform of the International Monetary Fund, the World Bank and the World Trade Organisation to adapt to changes in the global economy (Jelisavac Trošić, Todić, Stamenović, 2018, p. 254). The New International Economic Order is a goal that moves, strives for, and changes over time. Basic, fundamental principles remain, but the ways in which they can be achieved are constantly changing, complementing, new steps are being introduced, or technological advances and easier communication are being used to achieve them. It was not a surprise that the negotiations on concrete problems proved much more flexible and yielded new ideas and more pragmatic methods of resolving them than in the past. Today's reality is some mixture of the elements of the old and new international economic order. Today, common and usual global calls for a more sustainable economic growth and recovery, and recognising the achievement of this goal through inclusive multilateralism and the equal participation of all countries, very much resembles the UN Declaration on the NIEO. 


\section{Conclusions}

The New International Economic Order is almost a noble notion. The principles of the NIEO are not easy to implement, and the constant reminders and repetition of these basic principles are needed in order to counter resistance. It is also important to create a climate and systematic need for the implementation of these principles. Even today, there is a need for reminding on these basic NIEO principles in order to put them into practice, and even today there is a struggle for the same universal goals, as the removal of the disequilibrium that exists between the developed and the developing countries, progressive economic, political and social changes and others. The New International Economic Order demanded deep and fundamental reforms in the economic sphere, primarily international finance, investment in the world, relations in trade and credits, but in addition to these significant changes in the economic sphere, it also required significant changes in international law and world politics. It was a vision of what the world should look like in relation to the current situation and tendencies that prevailed at the time. However, this idea and initiative, when viewed from today's perspective, is still relevant and its essential proposals for change still sound fresh today. Is it because, in the meantime, the world has moved in another direction or because only a small part of this initiative has come to life in practice? But it can still be a platform for developing countries to fight for their common interests. Especially bearing in mind that all crises, those from the last century that gave birth to this initiative, as well as the global financial crisis and the current COVID-19 crisis, have the most devastating effects on the least developed countries.

\section{References}

Adamović, Lj. (Ed.), (1985). The economics of Non-alignment. (pp. 73-86). Belgrade, The Marxist Centre of the Organization of the League of Comunists of Belgrade, The Review of International Affairs, The Marxist Centre of the University of Belgrade.

Bekić, D. (1985). The evolution of the political economy of Non-alignment. in: Adamović, Lj. (Ed.), The economics of Non-alignment. (pp. 87-92). Belgrade, The Marxist Centre of the Organization of the League of Comunists of Belgrade, The Review of International Affairs, The Marxist Centre of the University of Belgrade. 
Bjelić P., Jelisavac Trošić S., Popović Petrović I. (2010). Savremena međunarodna trgovina, Institut za međunarodnu politiku i privredu, Beograd.

Ferguson Jr. C. (1977). The Politics of the New International Economic Order. Proceedings of the Academy of Political Science 32, no. 4: 142-58.

Frangeš, B. (1985). The New International Economic Order and the Role of Internal Factors in Non-Aligned Countries. in: Adamović, Lj. (Ed.), The economics of Non-alignment. (pp. 259-264). Belgrade, The Marxist Centre of the Organization of the League of Comunists of Belgrade, The Review of International Affairs, The Marxist Centre of the University of Belgrade.

Gilman, N. (2015). The new international economic order: A reintroduction. Humanity: An International Journal of Human Rights, Humanitarianism, and Development, 6(1), 1-16.

Jagdish Bhagwan, N., (Ed.), (1977). The New International Economic Order: The North-South Debate. Cambridge, The Massachusetts Institute of Techology.

Jelisavac Trošić S., Todić, D., Stamenović, M. (2018). Svetska trgovinska organizacija, životna sredina $i$ sistem zdravstvene zaštite. Beograd, Institut za međunarodnu politiku i privredu.

Jelisavac Trošić, S. (2015). Pregovori u okviru GATT i STO. Beograd, Institut za međunarodnu politiku i privredu.

Jelisavac Trošić, S. (2018). Serbia's Sustainable Development Strategy and Industrial Policy for the European Union and the World Trade Organization, in: M Yülek (ed.), Industrial Policy and Sustainable Growth, Springer, pp. 263-284. https:// doi.org/10.1007/978-981-105741-0_23

Kovač, O. (1985). The Economic Policy of Non-Alignment and Economic Development. in: Adamović, Lj. (Ed.), The economics of Non-alignment. (pp. 265-272). Belgrade, The Marxist Centre of the Organization of the League of Comunists of Belgrade, The Review of International Affairs, The Marxist Centre of the University of Belgrade.

Laszlo, E., Kurtzman, J. (Eds.), (1981). Political and Institutional Issues of the New International Economic Order. New York, Pergman Press.

Lozoya, J., Green, R. (Eds.), (1981). International Trade, Industrialization and the New International Economic Order. New York, Pergman Press. 
Mandi, P. (1975). The new order of world economy and the process of development. Occasional paper 75/5. Vienna, Vienna Institute for Development.

Mates, L. (1985). The Non-Aligned and the Division of the World into North and South. in: Adamović, Lj. (Ed.), The economics of Non-alignment. (pp. 73-86). Belgrade, The Marxist Centre of the Organization of the League of Comunists of Belgrade, The Review of International Affairs, The Marxist Centre of the University of Belgrade.

Mrkušić, Ž. (1985). The role of Non-Aligned Countries in Conceiving the New International Economic Order. in: Adamović, Lj. (Ed.), The economics of Non-alignment. (pp. 247-258). Belgrade, The Marxist Centre of the Organization of the League of Comunists of Belgrade, The Review of International Affairs, The Marxist Centre of the University of Belgrade.

Omotayo Olaniyan, R. (1987). The New International Economic Order (NIEO): A Review Nigerian Forum, March-April 1987, Nos $3 \& 4$.

Popović, T., Štajner, R. (Red.), (1981) Novi međunarodni ekonomski poredak putevi ostvarenja i perspektive. Finalna studija, Beograd, Konzorcijum instituta.

Raičević, J., Popović, T. (Eds.), (1977). Novi međunarodni ekonomski poredak. Beograd, Institut za međunarodnu politiku i privredu.

Ramphal, S. (1975). Towards the New International Economic Order. Occasional paper 75/4. Vienna, Vienna Institute for Development.

Singh Shankar, J. (1977). A New International Economic Order Toward a Fair Redistribution of the World's Resources. New York, Praeger Publishers.

United Nations (1974a). United Nations General Assembly Resolution 3201 (S-VI): Declaration on the Establishment of a New International Economic Order. 2229th plenary meeting. New York. 1. May 1974.

United Nations (1974b). United Nations General Assembly Resolution 3202 (S-VI): Programme of Action on the Establishment of a New International Economic Order. 2229th plenary meeting. New York. 1. May 1974.

United Nations (1974c). United Nations General Assembly Resolution 3281 (XXIX): Charter of Economic Rights and Duties of States. New York. 12 December 1974.

United Nations (2018). Resolution adopted by the General Assembly on 20 December 2018. A/RES/73/240. 
United Nations (2021). Goal 1: End poverty in all its forms everywhere. https://www.un.org/sustainabledevelopment/poverty/. Accessed 31/03/2021.

World Bank (2018). Nearly Half the World Lives on Less than $\$ 5.50$ a Day. Washington, October. 17, 2018

Zurawicki, L. (1982). The new international economic order: a view from the socialist corner, Intereconomics, ISSN 0020-5346, Verlag Weltarchiv, Hamburg, Vol. 17, Iss.2, pp. 91-96. 